\title{
Winter severity and anthropogenic factors affect spatial behaviour of red deer in the Carpathians
}

\author{
Katarzyna Bojarska ${ }^{1}$ (10 • Katarzyna Kurek ${ }^{1}$ - Stanisław Śnieżko ${ }^{1}$ - Izabela Wierzbowska ${ }^{2}$ - Wiesław Król ${ }^{1}$. Ewa Zyśk- \\ Gorczyńska $^{3}$ - Grzegorz Baś ${ }^{1}$. Elżbieta Widera ${ }^{2} \cdot$ Henryk Okarma ${ }^{2}$
}

Received: 4 March 2020 / Accepted: 23 June 2020 / Published online: 2 July 2020

(C) The Author(s) 2020

\begin{abstract}
Spatial ecology of red deer Cervus elaphus is shaped by both natural and anthropogenic factors. We used radio telemetry to investigate factors affecting habitat selection on two spatial scales, home range sizes and migratory behaviour of red deer $(N=8$ individuals) in two mountain ranges of the western Carpathians in 2004-2007. The two study areas differed in terms of environmental conditions: Beskid Sądecki had higher altitudes, higher human population and road density and milder winters than Beskid Niski. Red deer in both areas selected forests and avoided agricultural habitats on both spatial scales. Elevation affected site selection only in Beskid Sąecki: deer selected higher altitudes for their home ranges, but lower altitudes within them. Deer avoided major roads when selecting their home ranges in both sites, but only in Beskid Sadecki, they also avoided roads within their home ranges. Deer in both study sites selected locations closer to supplementary feeding sites in winter. In years with more severe winters, deer in Beskid Niski displayed seasonal migration to south-facing slopes. Deer in Beskid Sadecki showed short-distance altitudinal movements from low elevations in winter to high elevations in summer, and a short-term descent to low elevations in August-September. Our results fit the general concept that climatic conditions and human-related factors shape spatial behaviour in ungulates, and that snow conditions are particularly important for migration. Climate change will likely contribute to diminishing migration in red deer in the Carpathians.
\end{abstract}

Keywords Cervus elaphus $\cdot$ Habitat selection $\cdot$ Home range $\cdot$ Migration $\cdot$ Roads $\cdot$ Supplementary feeding $\cdot$ Western Carpathians

\section{Introduction}

Red deer Cervus elaphus is one of the most widespread wild ungulates in the world, and its spatial behaviour varies greatly throughout the species' range (Clutton-Brock et al. 1982). Red deer home range size and habitat selection are related to both

Communicated by: Dries Kuijper

Electronic supplementary material The online version of this article (https://doi.org/10.1007/s13364-020-00520-z) contains supplementary material, which is available to authorized users.

Katarzyna Bojarska

katbojarska@gmail.com

1 Institute of Nature Conservation, Polish Academy of Sciences, A. Mickiewicza 33, 31-120 Kraków, Poland

2 Institute of Environmental Sciences, Jagiellonian University, Gronostajowa 7, 30-387 Kraków, Poland

3 Glass Traps Foundation, Murarska 25/27/6, 54-135 Wrocław, Poland natural and anthropogenic factors. For instance, the size of home range in red deer is influenced by climate, forage quality and availability, topography, population density, predation and human infrastructure (Rivrud et al. 2010; Jerina 2012; Reinecke et al. 2014). As in other animal species, the habitat selection in red deer is an outcome of trade-offs between seeking the best foraging opportunities and shelter from weather, predators and human disturbance (Godvik et al. 2009). As a result, red deer tend to avoid manmade structures, like roads and recreational infrastructure (Coppes et al. 2017; Prokopenko et al. 2017). However, the resource selection is often scale-dependent, e.g. environmental variables may influence habitat choice differently at a broad landscape scale and within home ranges (Johnson 1980; McGarigal et al. 2016).

In European mixed forest, red deer feeds mainly on grass, sedges and concentrated food, e.g. twigs and bark of young trees and leaves of black berry Rubus spp. bushes (Gebert and Verheyden-Tixier 2001). Moreover, red deer is often supplementary fed to facilitate hunting and decrease damage to forest and agricultural crops (Putman and Staines 2004). 
In mountainous environments with substantial spatiotemporal variation in seasonal availability of forage, red deer and other ungulates often display seasonal movements between high-elevation areas in summer and lower winter ranges (Luccarini et al. 2006; Zweifel-Schielly et al. 2009). The main drivers for seasonal migration include phenological development of forage, its accessibility due to snow cover, intraspecific competition and predation (Mysterud et al. 2011; Bischof et al. 2012; Smolko et al. 2018). Winter severity, particularly snow conditions, is considered the most important trigger of downhill migration in cervids (e.g. Ball et al. 2001; Cagnacci et al. 2011; Rivrud et al. 2016). Recent studies revealed that in response to varying winter conditions, often only some of the individuals migrate (partial migration, Ball et al. 2001), or animals migrate only in certain years (facultative migration, Cagnacci et al. 2011). However, seasonal migration in ungulates is considered disappearing across the globe due to climate change, anthropogenic development and supplementary feeding (Bolger et al. 2008; Sawyer et al. 2013; Jones et al. 2014). Studying migration behaviour of species under various environmental conditions may offer an excellent opportunity to better understand the effect of winter severity on migration and may help to predict future impact of climate change on animal populations (Brinkman et al. 2005; Dingle and Drake 2007; Fieberg et al. 2008; Rivrud et al. 2010).

In the Carpathian Mountains, the red deer is the most common wild ungulate species, the most important game and a target for supplementary feeding. To our knowledge, the only published data on red deer spatial ecology in the Carpathians concerns male individuals in the Kremnica Mountains in Slovakia (Kropil et al. 2015; Smolko et al. 2018). In this paper, we aim to (1) report first data on red deer home range sizes and migratory strategies in two environmentally different study areas of the easternmost part of Western Carpathians, (2) investigate the effect of both natural and anthropogenic factors, on red deer habitat selection at two spatial scales: landscape scale (second-order selection) and within home ranges (third-order selection). We hypothesize that habitat selection by red deer in more human-dominated landscape of Beskid Sacdecki is more affected by anthropogenic factors than in less human-impacted Beskid Niski. We also predict that the relative importance of environmental factors shaping habitat selection differs across spatial scales. Furthermore, we expect that seasonal migration in red deer is related to winter severity.

\section{Study area}

We conducted the study in 2004-2007 in two mountain ranges in the easternmost part of the Outer Western Carpathian Mountains (south-eastern Poland): the Beskid Sadecki Mountains (hereafter Beskid Sadecki) and the Beskid Niski Mountains (Beskid Niski, Fig. 1). Although the two study sites are located only $30 \mathrm{~km}$ apart, they differ in terms of topography, habitat composition, climate and density of human infrastructure (Table 1). The study area located in Beskid Sąecki $\left(34 \mathrm{~km}^{2}\right)$ is characterized by higher, steeper mountains intersected by several built-up valleys and public roads with high traffic, especially on the main national road intersecting the northern corner of the area (Fig. 1). Beskid Niski encompasses ca $78 \mathrm{~km}^{2}$ of rolling hills with very sparse settlements and few public roads of relatively low traffic. Forests in both areas comprise mainly common beech Fagus sylvatica, silver fir Abies alba and Scotts pine Pinus sylvestris. Winters are generally harsher in Beskid Niski, but winter severity in both study sites varied among years during the study: winters 2004/2005 and 2005/2006 were characterized by more severe weather conditions than winter 2006/2007 (Table 1).

Both sites are popular touristic destinations for hikers and bikers, but Beskid Sadecki has higher numbers of tourists. The forests in both study areas are managed by the Polish State Forests for timber production and hunting. Game management involves hunting and year-round supplementary feeding of
Fig. 1 Seasonal red deer home ranges (combined 100\% MCP of all individuals) in two study sites located in two mountain ranges of western Carpathians, SE Poland: Beskid Sądecki (BS, 5 individuals) and Beskid Niski (BN, 3 individuals) based on 2253 telemetry locations in 2004 2007

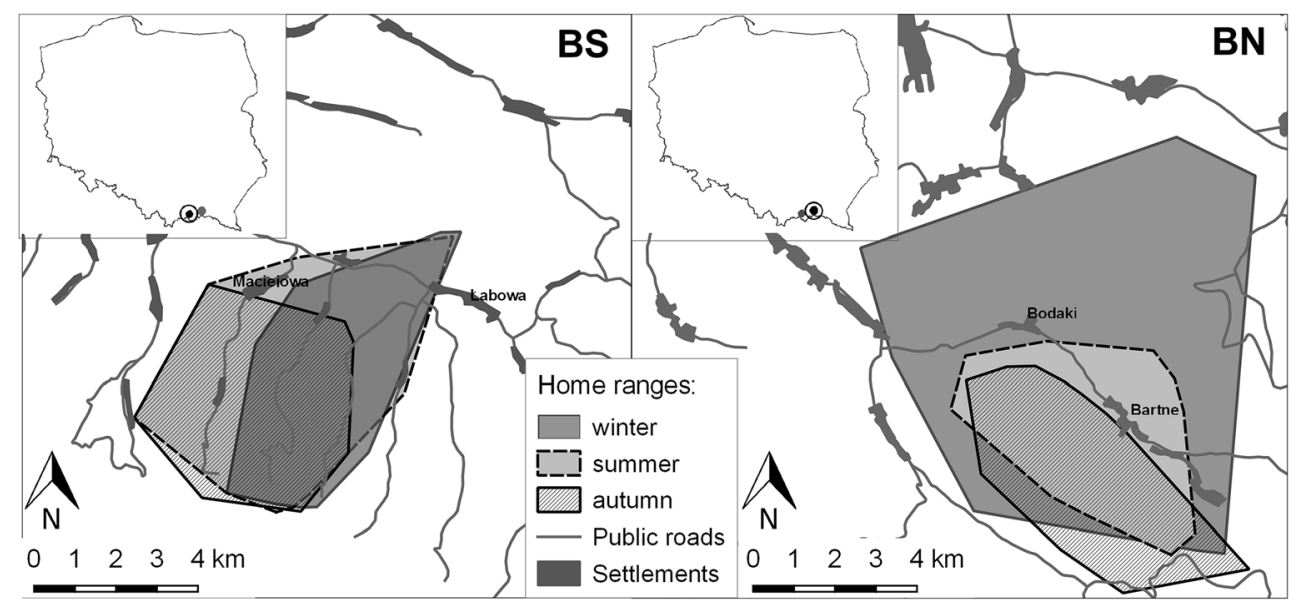


Table 1 Habitat and weather parameters in two study areas in Polish western Carpathians (the Beskid Niski Mountains and the Beskid Sąecki Mountains) where we conducted a telemetry study of red deer in 2004-2007. Weather parameters are averaged over the study period

\begin{tabular}{lll}
\hline & Beskid Niski & Beskid Sadecki \\
\hline Coordinates & $49.53-49.63^{\circ} \mathrm{N} 21.23-21.37^{\circ} \mathrm{E}$ & $49.48-49.54^{\circ} \mathrm{N} 20.75-20.91^{\circ} \mathrm{E}$ \\
Average altitude (and range) a.s.l. & $587(362-842) \mathrm{m}$ & $645(415-1082) \mathrm{m}$ \\
Annual precipitation* & $890 \mathrm{~mm}$ & $862 \mathrm{~mm}$ \\
Annual temperature* & $5.6^{\circ} \mathrm{C}$ & $7.1{ }^{\circ} \mathrm{C}$ \\
Winter average temperature & $-2.7^{\circ} \mathrm{C}$ & $-1.4^{\circ} \mathrm{C}$ \\
$\quad$ (Dec-Mar)* & & \\
Snow cover (duration, max depth):* & 110 days, $90 \mathrm{~cm}$ & 90 days, $65 \mathrm{~cm}$ \\
- Winter 2004/2005 & 119 days, $73 \mathrm{~cm}$ & 118 days, $55 \mathrm{~cm}$ \\
- Winter 2005/2006 & 52 days, $26 \mathrm{~cm}$ & 34 days, $14 \mathrm{~cm}$ \\
- Winter 2006/2007 & $0.36 \mathrm{~km} / \mathrm{km}^{2}$ & $0.69 \mathrm{~km} / \mathrm{km}^{2}$ \\
Density of public roads** & 25 people $/ \mathrm{km}^{2}$ & 48 people $/ \mathrm{km}^{2}$ \\
Human population density*** & & \\
Share of habitats:**** & $10.5 \%$ & $27.1 \%$ \\
- Settlements and agricultural habitats & $38.0 \%$ & $25.2 \%$ \\
- Deciduous forest & $1.3 \%$ & $10.5 \%$ \\
- Mixed forest & $50.2 \%$ & $37.0 \%$ \\
- Coniferous forest & &
\end{tabular}

*Institute of Meteorology and Water Management 2019, data from meteorological stations in Piwniczna (Beskid Sądecki) and Wysowa (Beskid Niski) for 2004-2007

**CODGiK (2019)

****entral Statistical Office (2006)

*****Corine Land Cover (2006) ungulates with hay, beet roots and maize at fixed feeding sites uniformly distributed over the study areas (Beskid Sacecki: 0.6 site $/ 10 \mathrm{~km}^{2}$, Beskid Niski 1.0 site $/ 10 \mathrm{~km}^{2}$ ). The hunting season for red deer lasts from the end of August till the end of February. The official statistics from game inventories in winter 2006/7 (based on track counts on snow) report red deer density of 3.6 individuals $/ \mathrm{km}^{2}$ in Beskid Sacdecki and 11.6 individuals $/ \mathrm{km}^{2}$ in Beskid Niski (State Forest Districts of Nawojowa and Gorlice), whereas aerial count with thermal detection and photography in 2015 yielded a collective density in both areas of 10.8 individuals $/ \mathrm{km}^{2}$ (Labaj and Okarma 2015). The ungulate community consists also of roe deer Capreolus capreolus and wild boar Sus scrofa. Three large carnivore species: grey wolf Canis lupus, European lynx Lynx lynx and brown bear Ursus arctos occur in both study areas.

\section{Materials and methods}

We trapped the red deer in 2004-2005 using $25 \times 25 \mathrm{~m}$ horizontal drop nets on treeless baited areas. In Beskid Sacecki, we radio-collared five individuals (four adult females and a subadult male) during two trapping events. In Beskid Niski, we radio-collared three adult females in one trapping event (Table S1). We anesthetized the animals with xylazineketamine mixture $(4 \mathrm{mg} / \mathrm{kg}+4 \mathrm{mg} / \mathrm{kg}$, Kreeger and Arnemo
1996). The radio-collars (ATS, USA) were set on the $150 \mathrm{MHz}$ waveband. We located red deer with VHF receivers (YAESU, USA) and three-element hand-held antennas (AF Antronics, Inc., USA) once per day every 1-6 days (on average every 3.6 days in Beskid Sądecki and 2.3 days in Beskid Niski, Table S1), mostly at diurnal hours (10\% of locations in Beskid Sadecki and 5\% of locations in Beskid Niski were obtained between sunset and sunrise). We used triangulations with bearings obtained from at least three receiving locations. We attempted to locate all individuals in each site within the shortest time possible. We digitalized the locations using TRACKER software (Camponotus AB and Radio Location Systems AB 1994).

We assessed habitat selection at two spatial scales: home range selection in relation to the study area (second-order selection) and selection of sites within the individual home ranges (third-order selection, Johnson 1980). To test which habitat characteristics influenced red deer habitat selection at both scales, we compared deer telemetry locations with random locations using generalized linear models (GLM) with binomial distribution and logit-link function in R 3.6.2 (R Core Team 2019) with a binary response variable (1: deer telemetry location, 0 : random point). These models predict relative probabilities that a point is a deer location (and not a random location) based on habitat variables. To evaluate second-order habitat selection, we generated random points 
(number equal to number of telemetry locations) within the whole study area, defined as $100 \%$ minimum convex polygon (MCP) of all telemetry locations with a 1-km buffer. We included the habitat type (three categories: agricultural land: joined Corine Land Cover 2006 class CLC 211, 231 and 242, deciduous forest: CLC 311, mixed and coniferous forest: CLC 243, 312 and 313), elevation (EU-DEM, European Environment Agency 2019) and distance to closest major road (country national or voivodship, CODGiK 2019) as explanatory variables.

To assess the third-order habitat selection, we compared deer locations to random locations generated within the seasonal home ranges $(100 \% \mathrm{MCP})$ of each radiocollared individual for three seasons: summer ranges (May-August), autumn ranges (September-November) and winter ranges (December-April), following natural seasonal cycles of the species in the Carpathian Mountains (Kropil et al. 2015). For each deer and each season, we used the same number of random points as there were telemetry locations. The explanatory variables in this analysis included the following: the type of habitat (as above), elevation, distance to closest paved road accessible for public (including minor local roads, CODGiK 2019) and interactions between season (as above) and habitat and season and distance to the closest supplementary feeding site. For both analyses (second- and third-order habitat selection), we performed model selection based on the Akaike Information Criterion (AICc) in the MuMIn package (Bartoń 2019) in R 3.6.2.

We estimated the annual home ranges using $100 \% \mathrm{MCP}$ (Hayne 1949). For individuals monitored for longer than 1 year, to include the whole monitoring period, we determined mean annual home ranges as averaged 12-month ranges moving in 3month intervals. Additionally, we estimated seasonal home ranges (100\% MCP) for three seasons (as above).

To assess whether the individuals within a study site should be considered as one group, for each telemetry location, we calculated the distance to the closest other individual as a nearest neighbour distance using NNJoin plugin (http:// plugins.qgis.org/plugins/NNJoin/) in QGIS v. 3.2.3
(Quantum GIS Development Team 2018). All other spatial analyses were also performed in QGIS v. 3.2.3.

\section{Results}

From 2004 to 2007, we obtained 2253 telemetry locations (Beskid Sądecki: 1043 locations; Beskid Niski: 1210 locations, Table S1). Though individuals within each study site used common home ranges, they were not close to each other most of the time (average inter-individual distances \pm SD: in Beskid Sądecki $1.48 \pm 1.25 \mathrm{~km}$, in Beskid Niski $2.13 \pm$ $1.35 \mathrm{~km}$ ). Only $21 \%$ of all telemetry locations in Beskid Sacecki and $4 \%$ of locations in Beskid Niski were closer than $200 \mathrm{~m}$ to another collared individual. Therefore, we treated data from all eight individuals as independent.

Red deer used habitats in a non-random manner, but factors affecting habitat selection varied between spatial scales and study areas (Tables 2 and 3). Deer avoided agricultural habitats and selected forests in both study sites and at both spatial scales (Fig. 2). Elevation did not affect deer site selection in Beskid Niski, whereas in Beskid Sądecki, deer selected higher altitudes in relation to the whole study area (second-order selection, Table 2) and lower altitudes within their home ranges (third-order selection, Table 3). Elevations of deer locations averaged by months showed clear altitudinal movements in Beskid Sądecki: deer used lower elevations during winter and moved to higher elevations in the period of MayJuly (Fig. 3). Moreover, they displayed an additional shift to low altitudes in August-September, followed by a return to high elevations in October (Fig. 3).

Deer at both study sites avoided major roads in relation to the study areas, whereas they avoided all paved roads within their home ranges in Beskid Sądecki, but not in Beskid Niski (Fig. 4). The analyses of third-order selection revealed seasonal differences in habitat selection: in winter, deer in Beskid Niski selected mixed and coniferous forest more than deciduous stands. Also, in winter in Beskid Sadecki, deer selected forested areas (and avoided agricultural areas) stronger than in other seasons (Fig. 2). Deer in both study areas selected

of 5 individuals in Beskid Sądecki and 1210 telemetry locations of 3 individuals in Beskid Niski). We provide model estimates, their standard errors and $p$ values
Table 2 Results of models (GLM) explaining the habitat selection of red deer in relation to the whole study area (second-order selection) in the western Carpathians, SE Poland in 2004-2007 (1043 telemetry locations

\begin{tabular}{|c|c|c|c|c|c|c|}
\hline \multirow[t]{2}{*}{ Model term } & \multicolumn{3}{|c|}{ Beskid Niski } & \multicolumn{3}{|c|}{ Beskid Sądecki } \\
\hline & Estimate & SE & $p$ & Estimate & SE & $p$ \\
\hline Deciduous forest & 3.036 & 0.299 & $<0.001$ & 1.922 & 0.398 & $<0.001$ \\
\hline Mixed \& coniferous forest & 3.083 & 0.296 & $<0.001$ & 3.480 & 0.368 & $<0.001$ \\
\hline Elevation & 0.001 & 0.001 & 0.326 & 0.003 & 0.001 & $<0.001$ \\
\hline Distance to major road & 0.000 & 0.000 & 0.043 & 0.000 & 0.000 & 0.014 \\
\hline
\end{tabular}


Table 3 Results of models (GLM) explaining the habitat selection of red deer within individual home ranges (third-order selection) in the western Carpathians, SE Poland in 2004 2007 (1043 telemetry locations of 5 individuals in Beskid Sacecki and 1210 telemetry locations of 3 individuals in Beskid Niski). We provide model estimates, their standard errors and $\mathrm{p}$ values

\begin{tabular}{|c|c|c|c|c|c|c|}
\hline \multirow[t]{2}{*}{ Model term } & \multicolumn{3}{|c|}{ Beskid Niski } & \multicolumn{3}{|c|}{ Beskid Sądecki } \\
\hline & Estimate & SE & $p$ & Estimate & SE & $p$ \\
\hline Deciduous forest & 2.525 & 1.076 & 0.019 & 2.068 & 0.543 & $<0.001$ \\
\hline Mixed and coniferous forest & 2.667 & 1.071 & 0.013 & 2.247 & 0.425 & $<0.001$ \\
\hline Elevation & 0.000 & 0.001 & 0.813 & -0.001 & 0.001 & 0.050 \\
\hline Distance to road & -0.001 & 0.000 & $<0.001$ & 0.001 & 0.000 & $<0.001$ \\
\hline Agricultural habitats $\times$ summer & -1.599 & 1.490 & 0.283 & -0.701 & 1.448 & 0.629 \\
\hline Deciduous forest $\times$ summer & -0.531 & 0.241 & 0.028 & 0.694 & 0.453 & 0.126 \\
\hline Mixed $\&$ coniferous forest $\times$ summer & -0.470 & 0.255 & 0.065 & 0.397 & 0.251 & 0.114 \\
\hline Agricultural habitats $\times$ winter & 0.177 & 1.126 & 0.875 & -15.51 & 321.400 & 0.962 \\
\hline Deciduous forest $\times$ winter & -0.228 & 0.218 & 0.297 & 1.597 & 0.462 & 0.001 \\
\hline Mixed and coniferous forest $\times$ winter & 0.160 & 0.219 & 0.467 & 0.768 & 0.220 & $<0.001$ \\
\hline Distance to feeding site $\times$ autumn & 0.000 & 0.000 & 0.195 & 0.000 & 0.000 & $<0.001$ \\
\hline Distance to feeding site $\times$ summer & 0.000 & 0.000 & 0.018 & 0.000 & 0.000 & 0.054 \\
\hline Distance to feeding site $\times$ winter & 0.000 & 0.000 & 0.295 & 0.000 & 0.000 & 0.348 \\
\hline
\end{tabular}

locations farther from supplementary feeding sites in summer and closer to them in winter (Table 3).

The ranking of models predicting red deer locations in relation to the whole study area showed that best models $(\triangle \mathrm{AICc}<2)$ included all three analyzed variables in both sites, although elevation was not included in the best of models in Beskid Niski (Table S2). At the within home range scale, the best models included all the variables in Beskid Sądecki, but interactions with season were not included in Beskid Niski (Table S3).

The yearly home ranges of individuals in Beskid Sądecki were smaller than in Beskid Niski (Table S1). Deer in both

Fig. 2 Relative probability predicted by GLM (with 95\% CI) of red deer location within their home ranges in relation to habitat type in the western Carpathians (a Beskid Niski, b Beskid Sądecki), SE Poland in 2004-2007 (1043 telemetry locations of 5 individuals in Beskid Sądecki, and 1210 telemetry locations of 3 individuals in Beskid Niski)

\section{a) Beskid Niski}

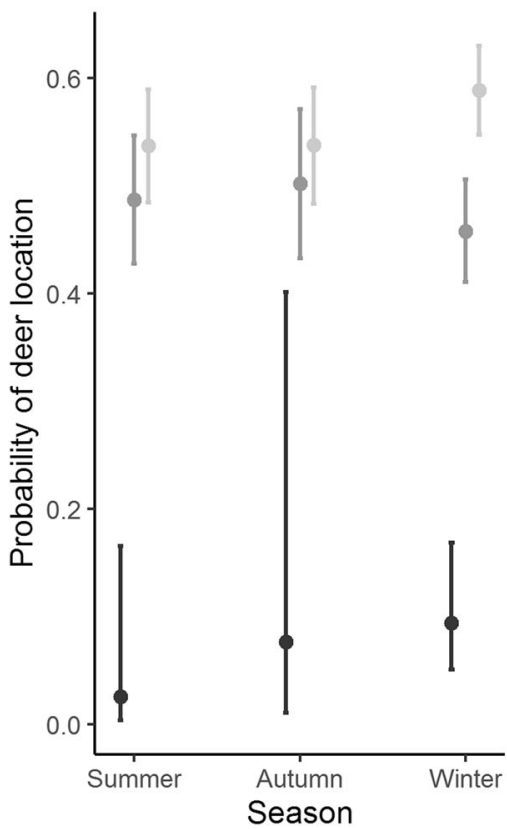

study sites used ranges of similar size in summer and autumn (Table S1, Fig. 5). Winter home ranges in Beskid Sądecki did not differ from other seasons, whereas in Beskid Niski, red deer used considerably larger ranges in winters 2004/2005 and 2005/2006 (Fig. 5). During these winter seasons, deer in Beskid Niski migrated to areas on slopes of southern exposition, ca $5 \mathrm{~km}$ from the centroids of summer and autumn ranges (Fig. 1). In winter 2006/2007, red deer in Beskid Niski did not migrate and their ranges were smaller than in previous winters (mean $\mathrm{MCP} \pm \mathrm{SD}$ $8.14 \pm 3.20 \mathrm{~km}^{2}$ ) and overlapped with summer and autumn ranges. Additionally, we observed variation in timing and

\section{b) Beskid Sądecki}

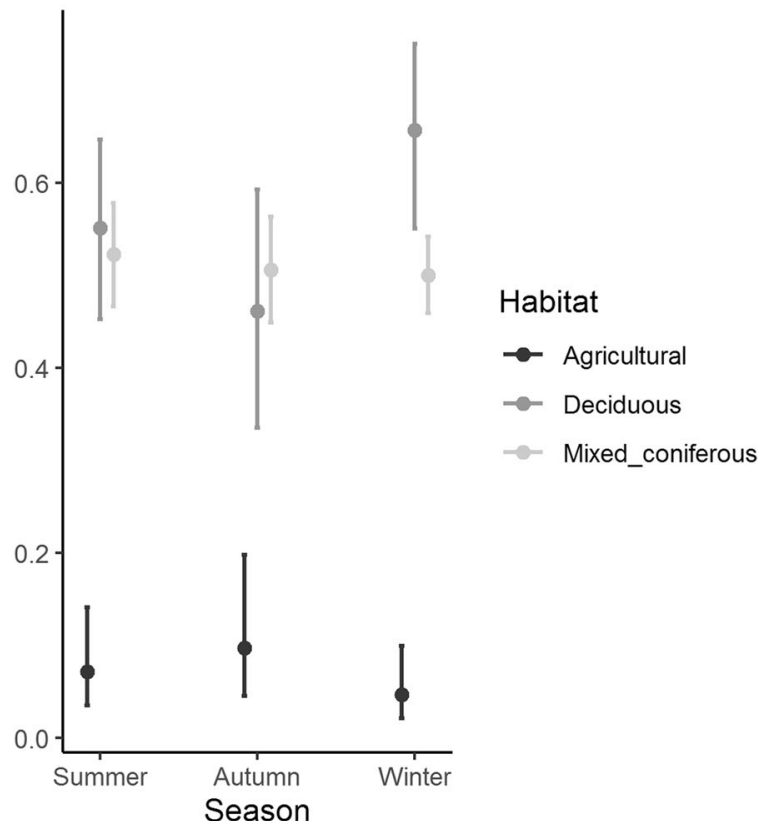




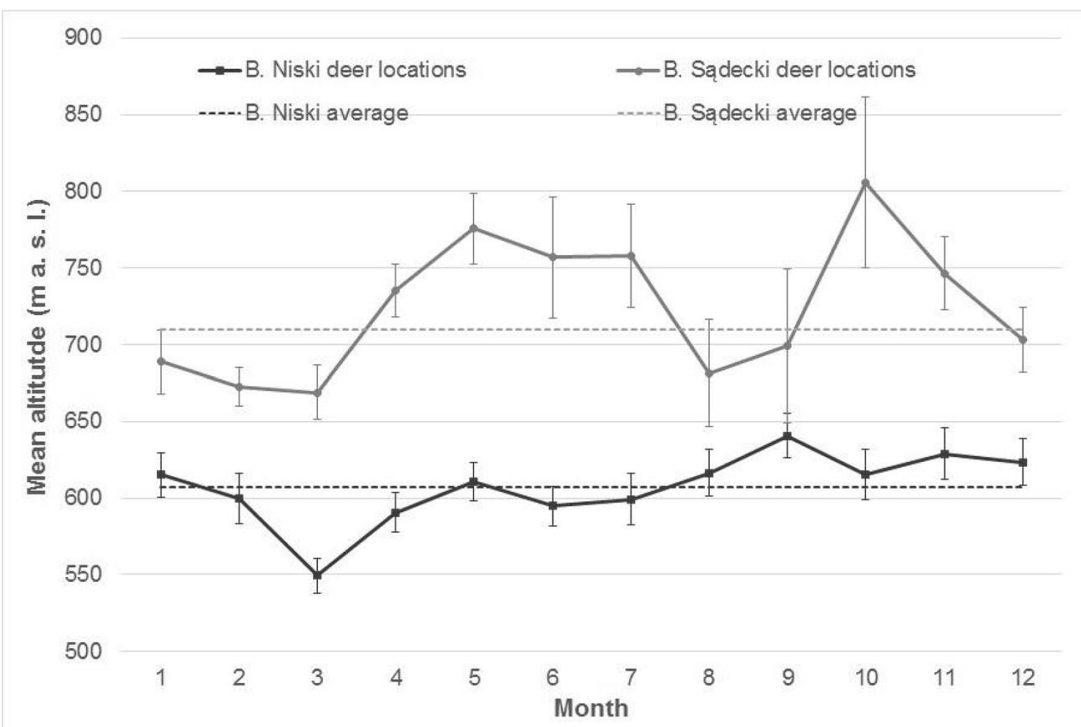

Fig. 3 Monthly altitude averages ( $\pm 95 \%$ confidence intervals) of telemetry locations of eight red deer in two study sites in the western Carpathians (Beskid Niski: 1210 locations and Beskid Sądecki, 1043 locations) in SE Poland

number of migrating individuals among years: in winter $2004 / 2005$, two of three females migrated at the beginning of March and came back to summer ranges in April (on 7th and 19th). In winter 2005/2006, all three individuals migrated, one of them at the end of January, and the other two at the beginning of March; all three females came back in the second half of April.

\section{Discussion}

Red deer spatial behaviour differed between the two study areas despite their close vicinity. Both in Beskid Niski and Beskid Sadecki, red deer avoided agricultural areas, likely because these open areas did not provide enough shelter from humans and adverse weather conditions. However, strong avoidance of agricultural habitats found in our study might be artificially enhanced by deficiency of locations obtained during nighttime, as deer tend to use safer habitats during daylight (Fattebert et al. 2019). Stronger selection of mixed and coniferous forest stands in winter observed in Beskid Niski was most probably a result of foraging on young firs and black berry bushes, which are preferred by red deer in winter (Jamrozy 1980; Krojerová-Prokešová et al. 2010).

Large, busy roads seemed to affect the placement of deer home ranges at both study sites. Dense network of smaller roads intersected deer home ranges the Beskid Sadecki area, which caused a fine-scale road avoidance in red deer. In Beskid Niski, the density of roads was very low; therefore, roads did not adversely affect red deer habitat selection within
Fig. 4 Relative probability predicted by GLM (with $95 \% \mathrm{CI}$ ) of red deer location in relation to distance to the closest major road in relation to the whole study area (a) and to any closest public paved road within the home range (b) in the Beskid Niski Mountains (1210 telemetry locations) and in the Beskid Sadecki Mountains (1043 telemetry locations) of the western Carpathians, SE Poland in 2004-2007 a) 2nd-order habitat selection

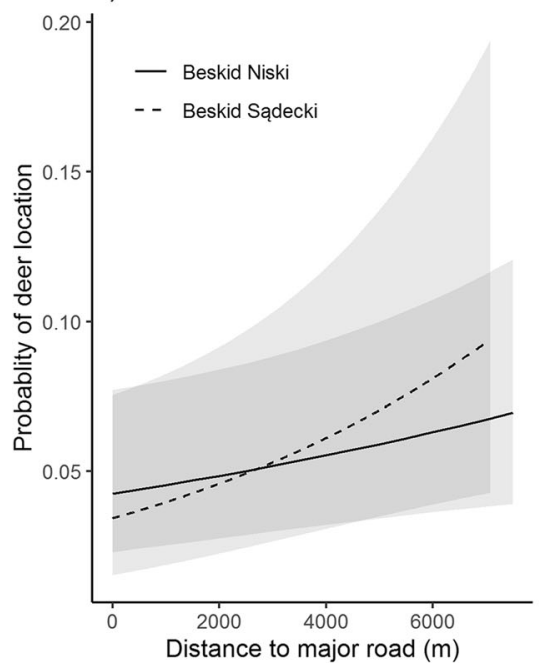

b) 3rd-order habitat selection

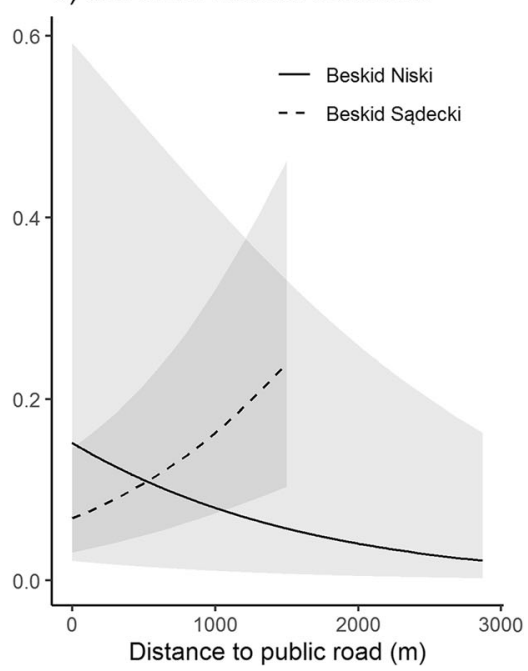




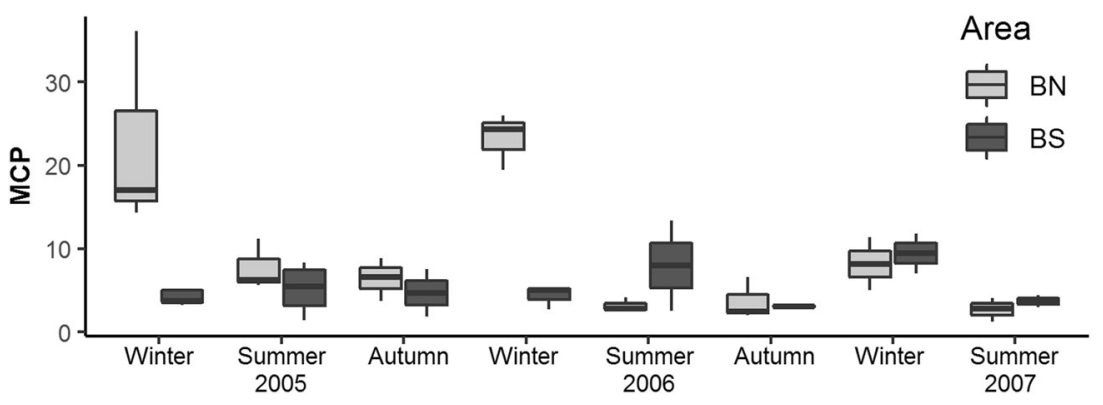

Fig. 5 Seasonal home ranges (MCP 100\%, km) of eight red deer in study sites in two study sites in the western Carpathians (BN: Beskid Niski, 1210 telemetry locations and BS: Beskid Sądecki, 1043 locations) in SE

the home ranges - for most of the year, the individual home ranges did not overlap with roads. Red deer in both study areas were attracted to feeding sites in winter, which is likely an outcome of lower availability of natural food sources.

Elevation played an ambivalent role in deer habitat selection. Deer generally tended to select their home ranges at higher altitudes, possibly to minimize human disturbance. On the other hand, within their high-altitude ranges, deer in Beskid Sacdecki avoided the highest areas, probably because they offered poor foraging and weather conditions and were more frequented by tourists, since many of touristic trails run along the mountain ridges. Interestingly, deer in Beskid Sacecki moved downhill in August, which was probably related to summer mowing of meadows in the valleys and subsequent appearance of young graminoid forage. However, we were not able to prove an actual increase in use of the meadows by deer, likely due to their mostly nocturnal usage by deer (Godvik et al. 2009).

It seems that different environmental conditions in the two study areas contributed to different behavioural strategies adopted by red deer in winter. Deer in Beskid Sądecki used the same ranges as in other seasons and displayed short-term, short-distance downhill movements. Deer in Beskid Niski increased their selection of mixed and coniferous forest stands and during more severe winters exhibited partial, facultative migration. The fact that deer in Beskid Niski did not migrate during the mildest winter suggests that the onset of this migration was induced by harsh winter conditions, corroborating other studies (Fieberg et al. 2008; Cagnacci et al. 2011). However, most deer in Beskid Niski did not begin to migrate until March despite snow cover depth of 50-70 $\mathrm{cm}$ in January and February. Very late downhill migration has been found in other deer species, particularly in areas with mild or unpredictable winter conditions (Fieberg et al. 2008; Cagnacci et al. 2011). Rising temperatures in March in our study area often cause consolidation of snow cover, which may further reduce forage availability and increase energy expenditure for movement (Moen 1976; Parker et al. 1984). Consequently, deer body condition deteriorates (Hobbs 1989; DelGiudice et al. 2002), while the risk of predation by wolves rises (Nelson and
Poland in 2004-2007. The middle bars represent the median values, the boxes middle $50 \%$ of values and the whiskers top and bottom $25 \%$ of values

Mech 1986; Gula 2004). The area to which deer migrated at the end of winter in Beskid Niski was located at lower elevation and on south-facing slopes, where spring thaws provided early access to evergreen bushes of black berry and emerging herbaceous vegetation. Therefore, it appears that snow quality, rather than snowfall or depth of snow cover, was the main trigger for migration in Beskid Niski.

Interestingly, even though Beskid Sądecki represented a more mountainous landscape in terms of elevation and slopes than Beskid Niski, none of the five radio-collared individuals migrated during the study period. This is in contradiction to results of other studies, which found that migration in ungulates is fostered by more diverse topography (Cagnacci et al. 2011; Mysterud et al. 2011). An explanation for the lack of migration in Beskid Sadecki may be high density of settlements and a very high-traffic road in the valley that fringed the area from the north, and thus constituted an obstacle for movement to slopes of southern exposition on the other side of the valley (Bolger et al. 2008; Sawyer et al. 2013). Therefore, the sedentary behaviour of deer in Beskid Sądecki may corroborate the general hypothesis about the adverse impact of human development on animal movement (Tucker et al. 2018). An alternative, non-exclusive interpretation can be that densely packed mountain ridges and valleys in Beskid Sądecki, coupled with slightly milder winters, provided a broad variety of conditions at small spatial scale, allowing red deer to utilize a full range of elevations and slope expositions without undertaking long-distance migrations, similarly to resident red deer in the Alps and the Carpathians (Luccarini et al. 2006; Kropil et al. 2015).

It is important to note that the results of this study have several limitations due to small sample size. First, we were not able to statistically quantify the impact of winter severity on deer behaviour, so our results on migration in Beskid Niski are rather observational in character. Secondly, it is possible that some deer did migrate in Beskid Sądecki, but we were not able to detect it due to small number of individuals and to only three full winter periods (Fieberg et al. 2008). However, despite their limitations, our findings constitute an important contribution to understanding spatial ecology of red deer in 
the Carpathians and should be treated as an introduction to further studies.

The results of our study fit the general concept that climatic conditions and human-related factors shape spatial behaviour in wildlife, and that snow conditions are particularly important for ungulate migration (Luccarini et al. 2006; Bojarska et al. 2019). Climate change projections predict milder winters (Jacob et al. 2014) and, with decreased snow cover, ungulate migration will become less common, as observed in other areas (Mysterud 2013). At the same time, urban sprawl increasingly contributes to the process of diminishing migration across the globe (Wilcove and Wikelski 2008; Tucker et al. 2018). In the face of development of human population and decreasing winter severity in the Carpathians, we predict that red deer migration will become an increasingly rare phenomenon in the future.

Acknowledgements We thank foresters from Forestry Districts of Nawojowa and Gorlice for their help during field work. The permit for animal trapping and handling was issued by the 1st Local Ethical Committee in Cracow (nr 47/OP/2003).

Funding information This study was funded by the European Commission within its Center of Excellence project IBAES (EVK2CT-2002-80009).

Open Access This article is licensed under a Creative Commons Attribution 4.0 International License, which permits use, sharing, adaptation, distribution and reproduction in any medium or format, as long as you give appropriate credit to the original author(s) and the source, provide a link to the Creative Commons licence, and indicate if changes were made. The images or other third party material in this article are included in the article's Creative Commons licence, unless indicated otherwise in a credit line to the material. If material is not included in the article's Creative Commons licence and your intended use is not permitted by statutory regulation or exceeds the permitted use, you will need to obtain permission directly from the copyright holder. To view a copy of this licence, visit http://creativecommons.org/licenses/by/4.0/.

\section{References}

Ball JP, Nordengren C, Wallin K (2001) Partial migration by large ungulates: characteristics of seasonal moose Alces alces ranges in northern Sweden. Wildlife Biol 7(3):39-48. https://doi.org/10.2981/wlb. 2001.007

Bartoń K (2019) Mu-MIn: multi-model inference. R Package Version 0.12.2/r18. https://R-Forge.R-project.org/projects/mumin/

Bischof R, Loe LE, Meisingset E, Zimmermann B, Van Moorter B, Mysterud A (2012) A migratory northern ungulate in the pursuit of spring: jumping or surfing the green wave? Am Nat 180:407424. https://doi.org/10.1086/667590

Bojarska K, Drobniak S, Jakubiec Z, Zyśk-Gorczyńska E (2019) Winter insomnia: How weather conditions and supplementary feeding affect the brown bear activity in a long-term study. Global Ecology and Conservation 17: e00523. https://doi.org/10.1016/j.gecco.2019. e00523

Bolger DT, Newmark WD, Morrison TA, Doak DF (2008) The need for integrative approaches to understand and conserve migratory ungulates. Ecol Lett 11:63-77. https://doi.org/10.1111/j.14610248.2007.01109.x

Brinkman TJ, Deperno CS, Jenks JA, Haroldson BS, Osborn RG (2005) Movement of female white-tailed deer: effects of climate and intensive row-crop agriculture. J Wildlife Manage 69:1099-1111. https:// doi.org/10.2193/0022-541x(2005)069[1099:mofwde]2.0.co;2

Cagnacci F, Focardi S, Heurich M, Stache A, Hewison AM, Morellet N, Kiellander P, John DC Linnell, Mysterud A, Neteler M, Delucchi L, Ossi F, Urbano F (2011). Partial migration in roe deer: migratory and resident tactics are end points of a behavioral gradient determined by ecological factors. Oikos 120(12): 790-1802. https://doi. org/10.1111/j.1600-0706.2011.19441.x

Camponotus AB and Radio Location Systems AB (1994) TRACKER: wildlife tracking and analysis software user manual. Version 1.1. Solna and Huddinge, Sweden. 37pp

Central Statistical Office (2006). Demographic yearbook of Poland. Statistical Publishing Establishment, Warsaw

Clutton-Brock TH, Guinness FE, Albon SD (1982) Red deer: behavior and ecology of two sexes. University of Chicago press 52:1001. https://doi.org/10.2307/4471

CODGiK (2019) Centralny Ośrodek Dokumentacji Geodezyjnej i Kartograficznej Głównego Urzędu Geodezji i Kartografii (Main Documentation Centre of Geodesy and Cartography of the Head Office of Geodesy and Cartography), http://www.serwisy.codgik. gov.pl (Accessed 11.05.2019)

Coppes J, Burghardt F, Hagen R, Suchant R, Braunisch V (2017) Human recreation affects spatio-temporal habitat use patterns in red deer (Cervus elaphus). PLoS One 12(5):e0175134. https://doi.org/10. 1371/journal.pone.0175134

Corine Land Cover (2006) European Environment Agency. Maps for Poland available from website of General Inspectorate of Environmental Protection: http://clc.gios.gov.pl/index.php?option= com_clc_2006 download_form\&view $=$ downloadformfiles\&Itemid $=327$

DelGiudice GD, Riggs MR, Joly P, Pan W (2002) Winter severity, survival, and cause-specific mortality of female white-tailed deer in north-central Minnesota. J Wildlife Manage 66:698-717. https:// doi.org/10.2307/3803136

Dingle H, Drake VA (2007) What is migration? Bioscience 57(2):113121. https://doi.org/10.1641/B570206

European Environment Agency (2019) Copernicus land monitoring service - EU-DEM. https://www.eea.europa.eu/data-and-maps/data/ copernicus-land-monitoring-service-eu-dem

Fattebert J, Morelle K, Jurkiewicz J, Ukalska J, Borkowski J (2019) Safety first: seasonal and diel habitat selection patterns by red deer in a contrasted landscape. J Zool 308:111-120. https://doi.org/10. 1111/jzo.12657

Fieberg J, Kuehn DW, DelGiudice GD (2008) Understanding variation in autumn migration of northern white-tailed deer by long-term study. J Mammal 89(6):1529-1539. https://doi.org/10.1644/07-mamm-a277.1

Gebert C, Verheyden-Tixier H (2001) Variations of diet composition of red deer (Cervus elaphus L.) in Europe. Mammal Rev 31:189-201. https://doi.org/10.1046/j.1365-2907.2001.00090.x

Godvik IMR, Loe LE, Vik JO, Veiberg V, Langvatn R, Mysterud A (2009) Temporal scales, trade-offs, and functional responses in red deer habitat selection. Ecology 90:699-710. https://doi.org/10.1890/ 08-0576.1

Gula R (2004) Influence of snow cover on wolf Canis lupus predation patterns in Bieszczady Mountains, Poland. Wildlife Biol 10(1):1724. https://doi.org/10.2981/wlb.2004.005

Hayne DW (1949) Calculation of size of home range. J Mammal 30:118. https://doi.org/10.2307/1375189

Hobbs NT (1989) Linking energy balance to survival in mule deer: development and test of a simulation model. Wildl Monogr 101:1-39 
Institute of Meteorology and Water Management (2019) Monthly metrological data of Poland. https://dane.imgw.pl/data/dane_pomiarowo obserwacyjne/dane meteorologiczne/. Accessed 15 Feb 2019

Jacob D, Petersen J, Eggert B, Alias A, Christensen OB, Bouwer LM, ..., Georgopoulou E (2014) EURO-CORDEX: new high-resolution climate change projections for European impact research. Reg Environ Chang 14:563-578. https://doi.org/10.1007/s10113-013-0499-2

Jamrozy G (1980) Winter food resources and food preferences of red deer in Carpathian forests. Acta Theriol 25:221-238. https://doi.org/10. 4098/AT.arch.80-17

Jerina K (2012) Roads and supplemental feeding affect home-range size of Slovenian red deer more than natural factors. J Mammal 93: 1139-1148. https://doi.org/10.1644/11-mamm-a-136.1

Johnson DH (1980) The comparison of usage and availability measurements for evaluating resource preference. Ecology 61(1):65-71. https://doi.org/10.2307/1937156

Jones JD, Kauffman MJ, Monteith KL, Scurlock BM, Albeke SE, Cross PC (2014) Supplemental feeding alters migration of a temperate ungulate. Ecol Appl 24:1769-1779. https://doi.org/10.1890/132092.1

Kreeger TJ, Arnemo JM (1996) Handbook of wildlife chemical immobilization. International Wildlife Veterinary Services, Laramie, Wyoming, USA

Krojerová-Prokešová J, Barančeková M, Šustr P, Heurich M (2010) Feeding patterns of red deer Cervus elaphus along an altitudinal gradient in the Bohemian Forest: effect of habitat and season. Wildl Biol 16:173-184. https://doi.org/10.2981/09-004

Kropil R, Smolko P, Garaj P (2015) Home range and migration patterns of male red deer Cervus elaphus in Western Carpathians. Eur J Wildlife Res 61:63-72. https://doi.org/10.1007/s10344-014-0874-4

Łabaj A, Okarma H (2015) Using aerial teledetection for estimating ungulate density in selected forest complexes. Unpublished report for the Polish State Forests, 1-11, Warsaw (in Polish)

Luccarini S, Mauri L, Ciuti S, Lamberti P, Apollonio M (2006) Red deer (Cervus elaphus) spatial use in the Italian Alps: home range patterns, seasonal migrations, and effects of snow and winter feeding. Ethol Ecol Evol 18:127-145. https://doi.org/10.1080/08927014.2006. 9522718

McGarigal K, Wan HY, Zeller KA, Timm BC, Cushman SA (2016) Multi-scale habitat selection modeling: a review and outlook. Landsc Ecol 31:1161-1175. https://doi.org/10.1007/s10980-0160374-x

Moen AN (1976) Energy conservation by white-tailed deer in the winter. Ecology 57:192-198. https://doi.org/10.2307/1936411

Mysterud A (2013) Ungulate migration, plant phenology, and large carnivores: the times they are a-changin. Ecology 94(6):1257-1261. https://doi.org/10.1890/12-0505.1

Mysterud A, Loe LE, Zimmermann B, Bischof R, Veiberg V, Meisingset E (2011) Partial migration in expanding red deer populations at northern latitudes-a role for density dependence? Oikos 120(12): 1817-1825. https://doi.org/10.1111/j.1600-0706.2011.19439.x

Nelson ME, Mech LD (1986) Relationship between snow depth and gray wolf predation on white-tailed deer. J Wildl Manag 50:471-474. https://doi.org/10.2307/3801108
Parker KL, Robbins CT, Hanley TA (1984) Energy expenditures for locomotion by mule deer and elk. J Wildlife Manage 48:474-488. https://doi.org/10.2307/3801180

Prokopenko CM, Boyce MS, Avgar T (2017) Extent-dependent habitat selection in a migratory large herbivore: road avoidance across scales. Landsc Ecol 32(2):313-325. https://doi.org/10.1007/ s10980-016-0451-1

Putman RJ, Staines BW (2004) Supplementary winter feeding of wild red deer Cervus elaphus in Europe and North America: justifications, feeding practice and effectiveness. Mammal Rev 34:285-306. https://doi.org/10.1111/j.1365-2907.2004.00044.x

QGIS Development Team (2018) QGIS geographic information system. Open Source Geospatial Foundation Project

R Core Team (2019) R: a language and environment for statistical computing. R Foundation for Statistical Computing, Vienna, Austria. URL http://www.R-project.org/

Reinecke H, Leinen L, Thißen I, Meißner M, Herzog S, Schütz S, Kiffner C (2014) Home range size estimates of red deer in Germany: environmental, individual and methodological correlates. Eur J Wildlife Res 60(2):237-247. https://doi.org/10.1007/s10344-013-0772-1

Rivrud IM, Loe LE, Mysterud A (2010) How does local weather predict red deer home range size at different temporal scales? J Anim Ecol 79:1280-1295. https://doi.org/10.1111/j.1365-2656.2010.01731.x

Rivrud IM, Bischof R, Meisingset EL, Zimmermann B, Loe LE, Mysterud A (2016) Leave before it's too late: anthropogenic and environmental triggers of autumn migration in a hunted ungulate population. Ecology. https://doi.org/10.1890/15-1191

Sawyer H, Kauffman MJ, Middleton AD, Morrison TA, Nielson RM, Wyckoff T (2013) A framework for understanding semi-permeable barrier effects on migratory ungulates. J Appl Ecol 50(1):68-78. https://doi.org/10.1111/1365-2664.12013

Smolko P, Kropil R, Pataky T, Veselovská A, Merrill E (2018) Why do migrants move downhill? The effects of increasing predation and density on red deer altitudinal migration in temperate Carpathian forests. Mammal Res 63(3):297-305. https://doi.org/10.1007/ s13364-018-0355-3

Tucker MA, Böhning-Gaese K, Fagan WF, Fryxell JM, Van Moorter B, Alberts SC et al (2018) Moving in the Anthropocene: global reductions in terrestrial mammalian movements. Science 359:466-469. https://doi.org/10.1126/science.aam9712

Wilcove DS, Wikelski M (2008) Going, going, gone: is animal migration disappearing. PLoS Biol 6(7):e188. https://doi.org/10.1371/journal. pbio. 0060188

Zweifel-Schielly B, Kreuzer M, Ewald KC, Suter W (2009) Habitat selection by an Alpine ungulate: the significance of forage characteristics varies with scale and season. Ecography 32:103-113. https:// doi.org/10.1111/j.1600-0587.2008.05178.x

Publisher's note Springer Nature remains neutral with regard to jurisdictional claims in published maps and institutional affiliations. 